
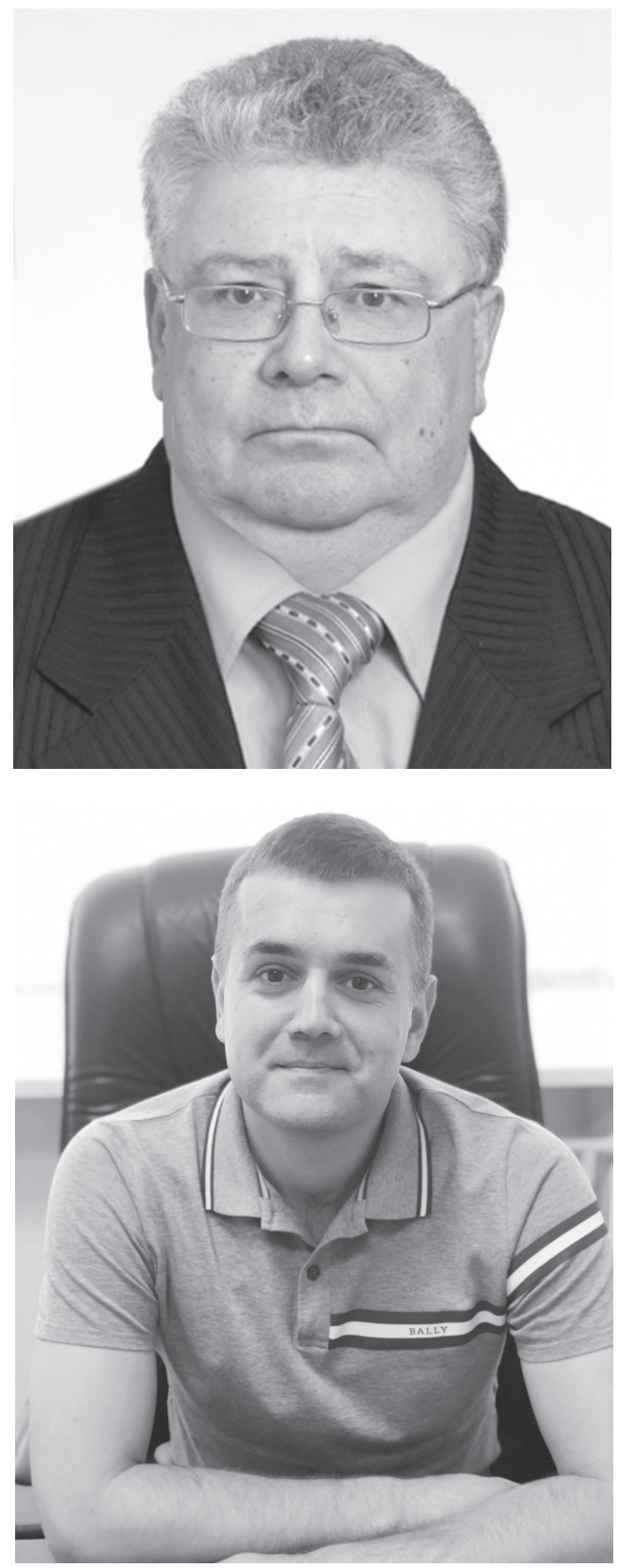

86,e-mail:platinum77@ukr.net

\section{Лукьянюк Александр Николаевич,}

аспирант кафедры общественного развития и общественно-властных отношений, Национальная академия государственного управления при Президенте Украинь,, 03057, г. Киев, ул. Эжена Потье, 20, тел.: (044) 45613 86, e-mail:platinum77@ukr.net ORCID:0000-0003-4762-3195
OR

\section{УДК: 321:353.1}

DOI: https://doi.org/10.32689/26172224-2019-5(20)-124-134

\section{Козаков Володимир Миколайович,} доктор наук з державного управління, професор, академік Украӥнської технологічної академї, професор кафедри суспільного розвитку та суспільно-владних відносин, Начіональна академія державного управління при Президентові України, 03057, м. Київ, вул. Ежена Потьє, 20, тел:050393 12 12, e-mail:v.kozakov@ ukr.net

$$
\text { ORCID: 0000-0003-1330-5244 }
$$

\section{Козаков Владимир Николаевич,}

доктор наук по государственному управлению, профессор, профессор кафедры общественного развития и общественно-властных отношении, Начиональная академия государственного управления при Президенте Украинь, 03057, г. Киев, ул.Эжена Потье, 20, тел.: (050) 3931212 , e-mail:v.kozakov@ukr.net

ORCID: 0000-0003-1330-5244

\section{Kozakov Volodymyr Nikolaevich,}

Doctor of Sciences in public administration, Professor, Professor of the Department of social developmentand social-power relations, National Academy of Public Administration under the President of Ukraine, 03057, Kyiv, Str. Ezhena Potie, 20, tel.: (050) 39312 12,e-mail:v.kozakov@ukr.net

ORCID: 0000-0003-1330-5244

\section{Лук'янюк Олександр Миколайович,} аспірант кафедри суспільного розвитку суспільно-владних відносин, Національна академія державного управління при Президентові України, 03057, м. Київ, вул. Ежена Потьє, 20, тел.: (044) 45613

ORCID: 0000-0003-4762-3195 
Lukianiuk Oleksandr Nikolaevich, postgraduate student the Dept. Public socialdevelopment and social-power relations National Academy for Public Administration under the President of Ukraine, 03057, Kyiz, Str. Ezhena Potie, 20, tel.: (044) 45613 86, e-mail:platinum77@ukr.net

ORCID: 0000-0003-4762-3195

\section{ФОРМУВАННЯ ТА РЕАЛІЗАЦІЯ ДЕРЖАВНО-ГРОМАДСЬКОї КОМУНІКАЦІЇ В СФЕРІ ЗАХИСТУ ПРАВ СПОЖИВАЧІВ}

Анотація. Обгрунтовано особливості функціонування державно-громадської комунікації у сфері захисту прав споживачів та наданні практичних рекомендацій щодо їх впровадження у практику демократичного врядування в Україні. Особливу увагу приділено аналізу концепції державної політики у сфері захисту прав споживачів, а також напрямів удосконалення взаємодії держави та громадянського суспільства у захисті прав споживачів. Визначено, що на противагу звичної практики державного управління, яка спирається на ієрархії та передбачає безумовне виконання наказів та розпоряджень, головними параметрами публічно-комунікативної сфери (публічна політика, публічне врядування, публічна комунікація) стають згода і договір. Традиційна адміністративно-управлінська діяльність приділяє переважно увагу праву та регламентам, публічно-комунікативна - нормам, колективним рекомендаціям, цінностям, пропозиціям, моральним угодам.

Змінити існуючу піраміду влади, зробити її відповідальною за розпорядження суспільними справами, а не бути розпорядником власності громадян, їхньої життєвої долі, загальнонародних ресурсів, - це сучасний шлях організації влади, реальний механізм її демократизації, підконтрольності суспільству і справжнього самоврядування. З'ясовано, що запорукою успіху для досягнення високих стандартів якості життя є співпраця державних органів, громадських організацій та споживачів. Споживчій культурі необхідно привчати дітей змалечку, адже належна якість товарів та послуг - це не тільки безпека для життя та здоров'я, а й повага до гідності людини.

Доведено, що сучасна модель взаємин держави і громадян має вибудовуватися не за традиційним принципом суб'єкт-об'єктних відносин (керуючікеровані), а на механізмах “комунікативної поведінки”, тобто суб'єкт-суб’єктних відносинах, на принципах визначення рівноправності як людини державної, так і людини “приватної”, що передбачає як головну демократичну процедуру “діалогову комунікацію” державної влади і “вільної громадськості”. Головна “відмінність діалогової моделі полягає в тому, що вона припускає своєрідну “горизонтальну рівність” учасників інформаційного обміну, на противагу “вертикальному” принципу “керівництва-підпорядкування”, властивого для моделі “віщання”. 
Ключові слова: публічне управління, державно-громадська комунікація, захист прав споживачів, консюмеризм, концепція державної політики у сфері захисту прав споживачів на період до 2020 p.

\section{ФОРМИРОВАНИЕ И РЕАЛИЗАЦИЯ ГОСУДАРСТВЕННО-ОБЩЕСТВЕННОЙ КОММУНИКАЦИИ В СФЕРЕ ЗАЩИТЫ ПРАВ ПОТРЕБИТЕЛЕЙ}

Аннотация. Обоснованы особенности функционирования государственно-общественной коммуникации в сфере защиты прав потребителей и предоставлении практических рекомендаций по их внедрению в практику демократического управления в Украине. Особое внимание уделено анализу концепции государственной политики в сфере защиты прав потребителей, а также направлений совершенствования взаимодействия государства и гражданского общества в защите прав потребителей. Определено, что в противовес привычной практики государственного управления, опирающейся на иерархии и предусматривающей безусловное выполнение приказов и распоряжений, главными параметрами публично-коммуникативной сферы (публичная политика, публичное управление, публичная коммуникация) становятся согласие и договор. Традиционная административно-управленческая деятельность уделяет преимущественно внимание праву и регламентам, публично-коммуникативная - нормам, коллективным рекомендациям, ценностям, предложениям, нравственным соглашениям.

Изменить существующую пирамиду власти: сделать ее ответственной за распоряжение общественными делами, а не быть распорядителем собственности граждан, их жизненных судеб, общенародных ресурсов это современный путь организации власти, реальный механизм ее демократизации, подконтрольности обществу и настоящего самоуправления. Обосновано, что залогом успеха для достижения высоких стандартов качества жизни является сотрудничество государственных органов, общественных организаций и потребителей. Потребительской культуре необходимо приучать детей с детства, ведь надлежащее качество товаров и услуг - это не только безопасность для жизни и здоровья, но и уважение к достоинству человека.

Доказано, что современная модель взаимоотношений государства и граждан должна выстраиваться не по традиционному принципу субъект-объектных отношений (управляющие-управляемые), а на механизмах “коммуникативного поведения”, то есть субъект-субъектных отношениях, на принципах определения равноправия как человека государственного, так и человека “частного”, предусматривающего как главную демократическую процедуру “диалоговую коммуникацию” государственной власти и “свободной общественности”. Главное отличие диалоговой модели состоит в том, что она предполагает своеобразное горизонтальное равенство участников информационного обмена, в противовес “вертикальному” принципу руководства-подчинения. 
Ключевые слова: публичное управление, государственно-общественная коммуникация, защита прав потребителей, консюмеризм, концепция государственной политики в сфере защиты прав потребителей на период до 2020 года.

\title{
FORMATION AND IMPLEMENTATION OF THE STATE-PUBLIC COMMUNICATION IN THE FIELD OF CONSUMER PROTECTION
}

\begin{abstract}
The article substantiates the peculiarities of functioning of the state-public communication in the sphere of the consumer rights protection and providing practical recommendations on their implementation in the practice of democratic governance in Ukraine. Special attention is paid to the analysis of the concept of the state policy in the field of consumer rights protection, as well as the directions of improving the interaction of the state and civil society in the protection of the consumer rights. It is determined that in contrast to the usual practice of the public administration that relies on the hierarchy and provides for unconditional execution of orders and commands, the main parameters of the public-communication sphere (public policy, public administration, public communication) are consent and agreement. The traditional administrative activity pays mostly attention to law and regulations, the public - communication to norms, collective recommendations, values, proposals, moral agreements.
\end{abstract}

To change the existing pyramid of power: to make it responsible for managing the public affairs and not to be the manager of the property of the citizens, their lives, national resources is a modern way of organizing power, a real mechanism for its democratization, control of the society and true self-government. It has been found that the key to success in achieving high standards of quality of life is the cooperation of the government agencies, public organizations and consumers. Consumer culture should be used to educate children from a young age, because the right quality of goods and services is not only safety for life and health, but also respect for the human dignity.

It is proved that the modern model of relations between the state and the citizens should be built not on the traditional principle of subject-object relations (control-managed), but on the mechanisms of "communicative behaviour", that is, subject-subject relations, on the principles of definition of equality of both the public and the "private" people, which envisages as the main democratic procedure the "dialog communication" of the state authorities and the "free public". The main "difference of the dialog model is that it assumes a kind of "horizontal equality "of the participants in the information exchange, as opposed to the "vertical" principle of "leadership-subordination" inherent in the "broadcasting" model.

Keywords: public administration, state-public communication, consumer protection, consumerism, concept of the public policy in the field of consumer rights protection until 2020. 
Постановка проблеми. Підписавши Угоду про асоціацію між Україною, з однієї сторони, та Європейським Союзом, Україна взяла на себе зобов'язання забезпечити високий рівень захисту прав споживачів.

В той же час потрібно констатувати, що в Україні відсутня цілісна система державного захисту прав споживачів, а це призводить до виникнення конкурентних переваг для недобросовісного бізнесу. Отже, внутрішній споживчий ринок більш ризикований та небезпечний для споживачів, порушення прав яких набули масового характеру. Більшість суб'єктів господарювання (виробників) втрачають свою конкурентоспроможність як усередині країни, так і на спільному з ЄС ринку. Поширення на внутрішньому ринку небезпечної продукції та продукції неналежної якості стає все більш загрозливим для здоров'я і життя населення [1].

Треба визнати, що на державному рівні не створено систему реалізації європейського принципу презумпції невинності споживача, доступну та прозору систему досудового розгляду скарг і реагування на результати незалежних споживчих досліджень.

Крім того, в Україні недооцінена роль громадянського суспільства, зокрема громадських об'єднань споживачів. Водночас в європейській практиці успішно здійснюються заходи $з$ державної підтримки діяльності неурядових організацій, що дає можливість більш ефективно використовувати ресурси у вирішенні питань інформування, консультування, споживчої освіти, визначення загроз, моніторингу ринку, здійснення контролю за виконанням органами державної влади своїх функцій, попередження виникнення корупційних факторів. Тому, як бачимо, аналіз основних напрямків формування та реалізації державно-громадської комунікації як важливого фактору щодо їх впровадження в практику демократичного врядування в Україні є актуальним і своєчасним.

\section{Аналіз останніх досліджень та} публікацій. У межах вітчизняної науки державного управління концептуальні засади теорії комунікації, питання розвитку масової й громадянської комунікації, зв'язків із громадськістю знайшло своє відображення в роботах таких учених, як: Е. Афонін, В. Бебик, М. Білинська, Т. Бутирська, О. Валевський, Т. Василевська, В. Голубь, Л. Гонюкова, Н. Грицяк, В. Гурковський, О. Дмитренко, Н. Дніпренко, В. Карлова, В. Козаков, В. Куйбіда, М. Логунова, Д. Неліпа, І. Пантелейчук, О. Петроє, Г. Почепцов, О. Пухкал, В. Ребкало, Є. Романенко, А. Савков, I. Сурай, С. Телешун та ін. Дослідженням проблем захисту прав споживачів, становлення конс'юмеризму присвячено наукові публікації, переважно економістів, а саме: А. Войчака, С. Дубенко, І. Дудла, А. Мазаракі, Н. Салухіна, Ф. Котлера, А. Павленко, В. Кардаша, О. Шафалюка, О. Язвінської тощо.

Тому, актуальність, теоретичне й практичне значення та недостатня розробленість цієї тематики визначило науковий інтерес автора саме до теоретико-методологічного обгрунтування впливу громадянської комунікації на демократичний розвиток державного управління в 
сфері захисту прав споживачів в Україні.

Мета статті полягає у теоретико-методологічному обгрунтуванні особливостей функціонування державно-громадської комунікації в сфері захисту прав споживачів та наданні практичних рекомендацій щодо їх впровадження в практику демократичного врядування в Україні.

Виклад основного матеріалу. Протягом останнього часу споживча політика Європейського Союзу зазначає перегляду з огляду на потреби громадян у поліпшенні захисту їхніх споживчих інтересів, а саме: забезпечення високого рівня захисту прав споживачів, головним чином через вдосконалення надання інформації з питань, що стосуються споживачів; поліпшення консультування та краще представництво інтересів споживачів; забезпечення ефективного застосування правил захисту прав споживачів, особливо через розвиток співробітництва між органами влади та організаціями, відповідальними за практичне виконання законодавства про захист прав споживачів, інформування, освіту та вирішення спорів, пов'язаних зі скаргами споживачів.

Змінити існуючу піраміду влади: зробити її відповідальною за розпорядження суспільними справами, а не бути розпорядником власності громадян, їх життєвих доль, загальнонародних ресурсів - це сучасний шлях організації влади, реальний механізм їі демократизації, підконтрольності суспільству й справжнього самоврядування. Запорукою успіху для досягнення високих стандартів якості життя є співпраця державних органів, громадських організацій та споживачів. Споживчій культурі необхідно привчати дітей змалечку, адже належна якість товарів та послуг - це не тільки безпека для життя та здоров’я, а й повага до гідності людини. Відомий науковець Ю. Габермас вважає, що “сучасна модель взаємин держави і громадян має вибудовуватися не за традиційним принципом суб'єкт-об'єктних відносин (керуючі - керовані), а на механізмах "комунікативної поведінки", тобто суб’єкт-суб'єктних відносинах, на принципах визначення рівноправності як людини державної, так і людини “приватної”, що передбачає як головну демократичну процедуру “діалогову комунікацію” державної влади і “вільної громадськості”. Головна "відмінність діалогової моделі полягає в тому, що вона припускає своєрідну “горизонтальну рівність" учасників інформаційного обміну, на противагу "вертикальному" принципу “керівництва-підпорядкування”, властивого для моделі “віщання” [2, c. 142].

Таким чином можна говорити, що державні органи влади й управління за демократичного устрою не можуть виконувати свої функції, не взаємодіючи на паритетних засадах із громадянами та їх об'єднаннями, не добиваючись і не завойовуючи їх підтримки та схвалення під час обговорення і прийняття рішень 3 тих чи інших питань соціально-економічного розвитку.

Документи "Програми розвитку ООН” дають можливість віднести до публічно-комунікативної сфери захисту прав споживачів такі ключові характеристики: 
- участь (всі громадяни мають голос у прийнятті рішень - прямо або за допомогою легітимних інститутів, які репрезентують їх інтереси; така широка участь будується на свободі асоціацій і слова, а також на здібності до конструктивного діалогу);

- верховенство права ( чесність i неупередженість правових структур, особливо тих, які забезпечують дотримання прав людини і права споживачів);

- прозорість (свобода інформаціï); ii повнота та доступність для всіх споживачів;

- чутливість (всі інститути чуйно реагують на потреби громадян);

- орієнтація на згоду (дотриманн балансу інтересів для досягнення широкого консенсу з питань про те, що більше усього відповідає потребам групи та якими засобами, за допомогою яких процедур цього належить досягти);

- справедливість (всі громадяни мають можливість покращувати свій добробут);

- результативність та дієвість (максимально ефективне використання ресурсів для задоволення потреб громадян);

- підзвітність (уряд, приватний бізнес і структури громадянського суспільства підзвітні громадськості та інституційним носіям права);

- стратегічне бачення (лідери, владні структури i громадськість спираються на довготривалі перспективи врядування та розвитку особи і чітко уявляють собі ті заходи, які необхідні для їх реалізації.

На противагу звичної практики державного управління, яка спирається на ієрархії та передбачає без- умовне виконання наказів та розпоряджень, головними параметрами публічно-комунікативної сфери (публічна політика, публічне врядування, публічна комунікація) стають згода і договір. Традиційна адміністративно-управлінська діяльність приділяє переважно увагу праву та регламентам, публічно-комунікативна - нормам, колективним рекомендаціям, цінностям, пропозиціям, моральним угодам. Традиційна влада здійснюється урядом, бюрократією, парламентом, публічна все більше залучає до своєї орбіти комісії, форуми, великі демократичні організовані групи. Якщо в системі державно-управлінських відносин інформація традиційно централізована та багато у чому закрита, то у публічно-комунікативній сфері вона відкрита і доступна для всіх. Реалізуючись за допомогою переговорів між державними, приватними та громадянськими структурами, які зацікавлені в спільних зусиллях для досягнення взаємоприйнятних результатів, публічна політика, врядування та комунікація здібні більш ефективно та результативно задовольняти суспільні потреби, тобто виробляти соціально значущі рішенНЯ.

Важливим напрямком функціонування державно-громадської комунікації в сфері захисту прав споживачів є консюмеризм (від англ. Consumer - споживач), як організований рух громадян, а також діяльність державних i громадських установ за розширення прав і впливу споживачів на виробників і торговців як у комерційній, так і позакомерційній сферах. 
Суб'єктами конс'юмеристської діяльності є: 1) громадські об'єднання споживачів; 2) органи державної влади; 3) підприємства.

Знаковим для світового конс'юмеристського руху стало 15 березня 1962 р. У цей день Президент США Джон Ф. Кеннеді звернувся 3 посланням до Конгресу США “Спеціальне повідомлення щодо захисту інтересів споживача”. Зокрема у ньому сказано: "Споживачі - це всі ми. Це найбільший економічний прошарок, який впливає на будь-яке приватне або державне економічне рішення. Але це єдиний голос, якого часто не чути”. У зверненні Джон Ф. Кеннеді проголосив чотири основних права споживачів: право на безпеку; право на інформованість [3, с. 268].

Громадські консюмерські структури відповідно до Закону України “Про захист прав споживачів" мають право:

- вивчати споживчі властивості продукції, попит на неї, проводити опитування населення для виявлення громадської думки про якість товарів, що випускаються і реалізуються, та ціни на них;

- проводити експертизу та випробування товарів (робіт, послуг);

- одержувати від органів державної влади і управління, органів міського самоврядування інформацію, необхідну для реалізації своїх цілей і завдань;

- сприяти державним органам у здійсненні контролю за якістю товарів (робіт, послуг), торговельного та інших видів обслуговування;

- організовувати юридичну і консультаційну допомогу споживачам відповідно до законодавства;
- вносити пропозиції для розробки нормативних документів, що встановлюють вимоги до якості товарів (робіт, послуг);

- представляти і захищати інтереси споживачів в органах державної влади й управління та місцевого самоврядування відповідно до законодавства.

Інноваційна перебудова всієї соціально-економічної політики, яка базується на інформаційних технологіях, дала змогу, перш ніж запропонувати товар для ринку, здійснити соціальні дослідження 3 метою виявлення об'єктивних потреб різних верств населення, рівня та характеру існуючого попиту, вимог до якості. Причому враховують також інтереси виробника-продавця. Посилюється боротьба за споживача, посилюється роль конкуренції у сфері якості товарів та послуг. Створено спеціальні маркетингові служби, які володіють інформацією і на ㄲi основі визначають: 1) попит; 2) наявність товарів та послуг на ринку; 3) витрати на їх виробництво; 4) найбільш раціональну технологію виробництва; 5) майбутніх партнерів зі спеціалізаціі; 6) майбутні договірні умови збуту товару тощо [4, с. 109].

Важливим аспектом з'ясування політико-правової природи об'єднань споживачів $є$ визначення їх впливу на державу. В Україні існує майже 100 громадських об’єднань i організацій споживачів. Найбільш впливовою серед них є Українська Асоціація споживачів (УАС ). Асоціація, як і багато інших громадських організацій, була створена у процесі перетворень періоду перебудови і офіційно зареєстрована Міністер- 
ством юстиції в 1989 р. об'єднує понад тридцять спілок споживачів. має складатись 3 чотирьох елементів - правового захисту, державного захисту (наприклад, створення профільного комітету ВРУ із захисту прав споживачів та структури при адміністрації Президента України), ринкового захисту та громадського захисту. Крім того, в Україні має бути створено єдиний представницький орган - Всеукраїнське об'єднання споживачів.

20 квітня 2018 року у Києві відбувся Всеукраїнський форум "Захищений Споживач”, на якому було визначено основні завдання захисту прав споживачів, а саме: по-перше, забезпечити права споживача таким чином, щоб не постраждав сумлінний бізнес, по-друге, підвищити суспільну свідомість та роль споживачів у самозахисті своїх прав та інтересів, та, по-третє, оптимально врегулювати законодавство та адаптувати українську систему захисту прав споживача до європейської [5, c. 43].

Можна виокремити такі напрями даного впливу, за В. Торяником:

- громадські об'єднання споживачів беруть участь у формуванні представницьких (законодавчих) органів держави та місцевого самоврядування;

- ефективність виконання державою своїх функцій певною мірою залежить від громадських об'єднань споживачів;

- представники громадських об'єднань споживачів можуть включатися до складу колегіальних державних органів 3 правом вирішального голосу тощо. Отож, основною метою діяльності громадських організацій у представництві інтересів громадян має бути:

- вдосконалення структур публічної влади з метою підвищення їх відповідальності та оптимізації взаємодії,

- гармонізація стосунків між державою і особою через утвердження структур громадянського суспільства [6].

\section{Програма захисту прав споживачів}

у м. Києві на 2019-2020 роки

Метою програми захисту прав споживачів у м. Києві на 2019-2020 роки є створення та впровадження ефективної системи захисту прав споживачів, зокрема:

- забезпечення конституційних гарантій безпеки та якості споживання, в тому числі шляхом унеможливлення зниження досягнутого рівня захисту прав споживачів;

- підвищення рівня споживчої грамотності;

- забезпечення впровадження прозорих та ефективних механізмів взаємодії державних органів, органів місцевого самоврядування, громадських об'єднань споживачів, представників бізнесу у сфері здійснення захисту прав споживачів;

- підвищення ефективності системи захисту споживачів від небезпечної продукції, що може заподіяти шкоду життю, здоров'ю, майну споживачів, навколишньому природному середовищу, в тому числі шляхом підвищення ефективності державного ринкового нагляду;

- упередження порушень, а не констатація їх фактів, основною метою програми є моніторинг продукції на території м. Києва; 
- у програмі приймають участь усі зацікавлені організації, а саме: Киїська міська державна адміністрація, Національна поліція, Державна фіскальна служба, районні державні адміністрації, Служба безпеки, громадські об'єднання споживачів та інші [7].

Хотілося б окремо відмітити необхідність запровадження на програмному рівні електронної системи сповіщення про неякісні товари, що забезпечить появу на ринку тільки такої продукції, яка не зашкоджує здоров'ю або безпеці споживачам. Це необхідно не лише для захисту споживачів, але і захисту економічних операторів від нечесної конкуренції.

Така система оповіщення повинна бути відкрита для всіх користувачів інтернету із зручним пошуком по категоріях товарів, фотографіями та повним описом потенційно небезпечних товарів і їх ризиків.

Система спостереження за ринком, що враховує різні критерії безпеки споживчої продукції, має принципове значення для зміцнення впевненості споживачів і підвищення добробуту громадян.

Розв'язання проблем можливе шляхом застосування комплексного підходу до вирішення питань захисту прав споживачів, що передбачає розвиток та взаємодію всіх складових системи захисту прав споживачів в Україні, зокрема правового забезпечення, державного захисту прав споживачів, ринкового та громадського захисту прав споживачів.

Висновки та перспективи подальших досліджень. Таким чином, можна зробити висновок, що захист прав споживачів є комплексною, ба- гато аспектною проблемою, яка безпосередньо пов’язана із зміцненням національної безпеки держави та захистом ii громадян. В умовах, що склалися, головні напрямки державної політики в галузі захисту прав споживачів повинні обіймати контрольну, профілактичну, ідеологічну, координаційну та інформаційно-аналітичну функції, що забезпечить українським громадянам необхідну підтримку та захист.

\section{СПИСОК ВИКОРИСТАНИХ ДЖЕРЕЛ}

1. Про схвалення Концепції державної політики у сфері захисту прав споживачів на період до 2020 року: розпорядження Кабінету Міністрів України від 29 березня 2017 р. № 217-p [Електронний ресурс]. ежим доступу: https://www.kmu. gov.ua/ua/npas/249869713

2. Хабермас Ю. Демократия. Разум. Нравственность / Ю. Хабермас. М.: Академия, 1995. 245 с.

3. Конак С. I. Особливості процесів захисту прав споживачів в Україні/ Є. I. Конак // Молодий вчений. № 2 (42). лютий, 2017 р. С. 268.

4. Салухіна Н. Г. Захист прав споживачів : навч. посіб. / Н. Г. Салухіна, О. М. Язвінська, О. І. Башкатова. К. : МАУП, 2007. 382 с

5. В Україні відбувся перший форум щодо захисту прав споживачів [Електронний ресурс]. Режим доступу:https://day.kyiv.ua/uk/ news/230418-v-ukrayini-vidbuvsyapershyy-forum-shchodo-zahystuprav-spo

6. Торяник В. Обєднання споживачів як громадські органи / В. Торяник // Наук. вісн. Ужгородського ун-ту. Серія : Політологія. Соціологія. Філософія. Вип. 15, 2010. С. 43. 
7. Про затвердження плану заходів 3 реалізації Концепції державної політики у сфері захисту прав споживачів на період до 2020 року: Кабінет Міністрів України від 27 грудня 2017 р. № 983-р [Електронний pecypc]. Режим доступу: https:// ckorykivska-gromada.gov.ua/kabinetministriv-ukraini-rozporyadzhennyavid-27-grudnya-2017-r-№-983

\section{REFERENCES}

1. Rozporiadzhennia Kabinetu Ministriv Ukrainy "Pro skhvalennia Kontseptsii derzhavnoi polityky u sferi zakhystu prav spozhyvachiv na period do 2020 roku" : vid 29 bereznia 2017, № 217-r [Decree of the Cabinet of Ministers of Ukraine "On approval of the Concept of state policy in the field of consumer rights protection for the period up to 2020” from March 29 2017, № 217-p]. (n.d.). wrø.kmu.gov.ua. Retrieved from https://www.kmu.gov.ua/ua/ npas/249869713 [in Ukrainian].

2. Khabermas, Yu. (1995). Demokratiia. Razum. Nravstvennost [Democracy. Reason. Morality]. Moscow: Akademyia [in Russian].

3. Konak Ye. I. (2017). Osoblyvosti protsesiv zakhystu prav spozhyvachiv $\mathrm{v}$ Ukraini [Features of Consumer Protection in Ukraine]. Molodyi vchenyi-
Young Scientist, 2(42), 267-271 [in Ukrainian].

4. Salukhina N. H., Yazvinska O. M., Bashkatova O. I. (2007). Zakhyst prav spozhyvachiv [Consumer Protection]. Kyiv: MAUP [in Ukrainian].

5. V Ukraini vidbuvsia pershyi forum shchodo zakhystu prav spozhyvachiv [The first consumer rights forum was held in Ukraine]. (April 23, 2018). wrer.unian.ua. Retrieved from https:// www.unian.ua/common/10091123v-ukrajini-vidbuvsya-pershiy-forumshchodo-zahistu-prav-spozhivachiv. html [in Ukrainian].

6. Torianyk V. (2010). Obiednannia spozhyvachiv yak hromadski orhany [Consumer Association as Public Authorities]. Naukovyi visnyk Uzhhorodskoho universytetu. Seriia : Politolohiia, Sotsiolohiia, Filosofiia - Scientific Bulletin of Uzhhorod University. Series: Political Science, Sociology, Philosophy, 15, 43-46 [in Ukrainian].

7. Pro zatverdzhennya planu zakhodiv z realizatsiyi Kontseptsiyi derzhavnoyi polityky u sferi zakhystu prav spozhyvachiv na period do 2020 roku: Kabinet Ministriv Ukrayiny vid 27 hrudnya 2017 r. № 983-r Kyiv - [Elektronnyy resurs]. - Rezhym dostupu: https:// ckorykivska-gromada.gov.ua/kabinetministriv-ukraini-rozporyadzhennyavid-27-grudnya-2017-r-№-983 